\title{
鉄鋼材のマテリアルフローを基にした各種製品における 回収率の導出手法の開発
}

\section{醍醐市朗松野泰也足立芳寛}

東京大学大学院工学系研究科マテリアル工学専攻

J. Japan Inst. Metals, Vol. 70, No. 2 (2006), pp. 114-117

(C) 2006 The Japan Institute of Metals

\section{Development of Methodology for Quantifying Collection Ratio of Post-Consumer Products Based on Material Flow of Steel}

Ichiro Daigo, Yasunari Matsuno and Yoshihiro Adachi

Department of Materials Engineering, Graduate School of Engineering, University of Tokyo, Tokyo 113-8656

Some post-consumer products are not collected appropriately and are remained or disposed by unconventional methods. In order to conserve resources, the collection ratio of such products should be increased. To date, few definitive methods to quantify the collection ratio have been developed because the amount of dissipative products cannot be measured. In this paper, a new statistical method was developed to quantify the collection ratio of post-consumer products. This method is based on the identification of dynamic material flow of steel used in such products. The collection ratios of buildings, constructions, and machines were estimated. The amount of discarded post-consumer products during a year was calculated dynamically from their lifetime distributions and production history in which steel was used prior to that year. Uncertainty derived from the lifetime distributions was considered in the calculations. Finally, the collection ratios of the products were obtained with uncertainty as 1.00 (buildings), $0.00-0.22$ (constructions), and 0.39-0.53 (machines).

(Received October 25, 2005; Accepted December 2, 2005)

Keywords: material flow analysis, population balance model, lifetime distribution, dissipative materials

\section{1. 緒言}

資源循環を考慮する上で，使用済み製品の回収工程におけ る損失量を把握することは，その量の大きさから重要である と考えられる1)。しかし，資源循環を評価する指標として用 いられているリサイクル率に，回収工程における損失分を考 慮した例はほとんどなく, 製品寿命が短い容器において見る ことができる程度である ${ }^{2)}$.これに対し, 製品需要量の動的 な分析により, 将来に渡る使用済久製品排出量の推計に関す る研究が, 建築3), 電気機器4,5), 自動車6)などで行われてい る.

一方, 資源循環を把握するための研究として MFA/SFA (Material flow analysis/Substance flow analysis)が行われて いるが，全てのマテリアルフローを把握した研究は少ない. 著者らは，既報1)において，動的なマテリアルフローを考慮 することで, 回収工程の損失を蓄積増分と区別できることを 示し，全てのマテリアルフローを把握した．また，他にもい くつかの研究7-10)において, 視認できない回収工程における 損失量の把握は試みられているが, 既往の研究において用い られた回収率は, 実測による把握が困難な量であるため, 関 連業界へのヒアリングにより得た感覚的な值を用いざるを得 なかった. そこで, 本研究では, 統計值から数理処理により 回収率を定量的に推定する手法を構築することを目的とする.

\section{2. 研 究 方 法}

\section{1 回収率の定義}

本研究に打ける回収率とは, Fig. 1 に示すように, 使用済 み製品として排出されたと推計されたものの中に含まれる素 材の量(1)を分母にとり, 素材の再生プロセスに投入された 量 (3)を分子にとった割合である.ここで損失されるもの は, 未回収となった製品中の素材量と, 回収された製品から 分離・分別工程において回収できなかった素材量である.

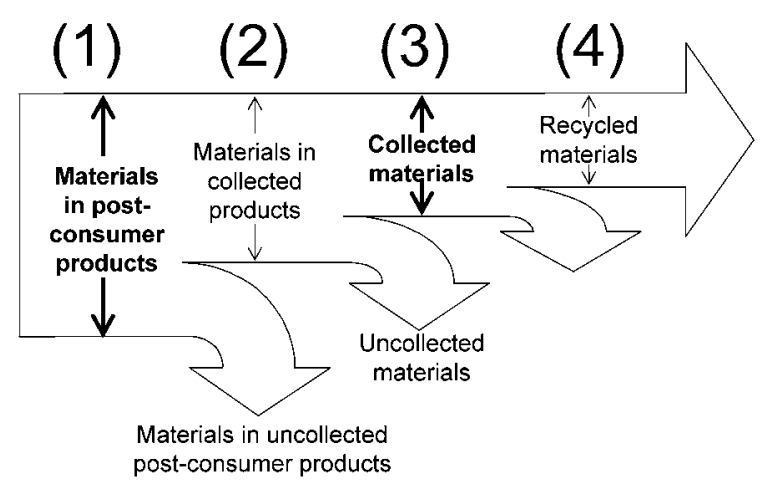

Fig. 1 Schematic illustration of material flow from discarded materials as components of post-consumer products to recycled materials. 
一般的に回収率とは, Fig. 1 に示す，回収された製品中の素 材量 (2)を分母としている. また, 本研究で(1)から(2)で未 回収分と説明しているものは, 社会蓄積量として計上されて いる.

\section{2 使用データ}

本研究では, 汎用素材である鉄鋼材のマテリアルフローに 着目して, 各種製品回収率の導出を試みた。 そのため, 対象 となる製品は，鉄鋼材の用いられている製品に限定されると ともに，鉄鋼材の統計区分からの制約を受ける. 製品分類 は, 建築, 土木, 自動車, 機械, 容器, その他製品の 6 種 類の用途分類とした.なお，機械には機械類と自動車以外の 輸送用機器を含めた.

回収率の分母となる使用済久製品の中に含まれる素材の排 出量(1)は, 先述したように, 製品として使用されたのち, 使用済久製品として排出される量を把握する必要があり，把 握が困難である。これは, 消費者 (排出拠点)や回収業者 (回 収拠点) が, 多数かつ散在しているため, 実測困難であるこ とが一因であると考えられる、ただし, 製品によっては例外 もあり，自動車のような登録制度を持った製品は，実際の使 用済久製品排出量を把握することができる11). また, 容器 製品は主に飲料缶や食料缶に用いられおり，使用期間が統計 值の期間 1 年と比較して短いため, 使用済久製品排出量が 同年の製品需要量と等しいと仮定した. それ以外の製品につ いては, 製品が寿命分布 (使用年数分布)を持つことに着目 し, 過去の製品需要量と当該製品の寿命分布から, 使用済み 製品排出量を導出するポピュレーションバランスモデル (Population Balance Model: PBM) $)^{4,7,12)}$ を適用した.これに より, 使用済み製品の中に含まれる素材の排出量 (1)は, 過 去からの鋼材の国内需要量に関する統計の履歴13,14) と, 製品 の寿命分布 $7,12,15,16)$ から推計できる. なお, 間接輸出入量 (製 品として輸出入された量) はヒアリングにより得た. 自動車 と容器以外の 4 種類の製品寿命分布を次のように設定し た. 建築と土木用途製品の寿命分布は, 建築物の実際の寿命 分布を同定した既往論文 ${ }^{15)}$ に従い, 形状母数 3.127, 尺度母 数 40.44, 平均 28.4 年となるワイブル分布を残存確率分布 関数として用いた. 機械とその他製品の寿命分布は，一般的 な分布関数の正規分布を確率密度関数として用いた. 分布の 平均は, 文献や既往論文 ${ }^{16)}$ から得てともに 12.1 年とし, 分 散は平均の 2 倍の期間において $99 \%$ が廃棄されるよう12)設 定し，ともに 4.7 となった.

回収率の分子となる再生素材の原料としてのスクラップ回 収量 (3) は, 鉄源に関する統計值 ${ }^{17)}$ を用いた。 な抒, 本研究 に拈けるスクラップ回収量は, 統計值の国内市中スクラップ 回収量から加工スクラップ回収量を差し引いた老廃スクラッ プ量である. 老廃スクラップには, 補修に伴い発生したスク ラップも含まれるが, 本研究では, 全て使用済久製品から発 生したものと仮定した.

回収率について, 自動車, 容器, その他製品の回収率を, それぞれ以下の理由により決定した. 自動車の回収率は, 中 古品輸出分が未回収分であると考えられるため, 把握されて いる中古品輸出台数 ${ }^{18)}$ から回収率を求めた. 容器の回収率

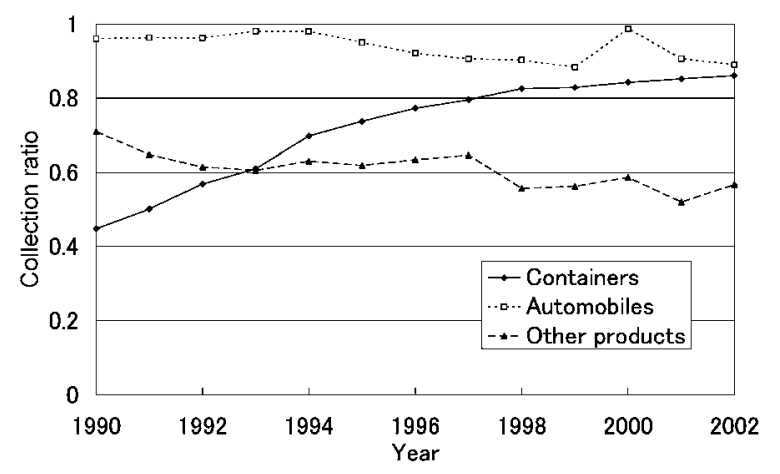

Fig. 2 Collection ratios of automobiles, containers, and other products obtained during 1988-2000.

は, 容器の主要製品であるスチール午の各年のリサイクル 率19)が把握されているため，それを採用した。さらに，そ の他製品は，その多くが二次製品としてボルト，ナット，ネ ジ，バネなどに用いられて抢り，本来は他の 4 用途に配分 されるべきものであるため, その回収率は, 全製品の回収率 の平均值とし, スクラップ回収量を全ての製品から排出され る使用済み鋼材の総量により除して得られた. 得られた回収 率の経年変化を Fig. 2 に示す.

\section{3 不確実性}

中島ら ${ }^{20)}$ が指摘するように, 生産統計は, 用途別に区分 されている一方, スクラップ統計は, 検収時のスクラップ種 に区分されているため, 用途別の観点からは, 回収されたス クラップは総量でしか把握できない。 また, 従来の使用済み 製品や素材の排出量を予測した研究1,3-7,12,16)において, 寿命 分布は寿命分布関数に従って一意に決定されていた. しか し, 数式化された寿命分布関数は, 小松が建築物を評価対象 として示した15)ように，実際の統計值から得られる寿命分 布を $95 \%$ 信頼幅に含む分布関数である.

本研究では, 統計区分の相違から 3.1 節で記す手法を, 寿 命分布の信頼幅を考慮して 3.2 節で記す手法を適用した.

\section{3. 手法の構築}

\section{1 回収率導出方法}

生産統計とスクラップ統計の区分が異なることから, 式 (1) に示す関係式から残差和が最小となる, 建築, 土木, 機械の 3 つの用途の回収率を導出した.

$$
S_{y}=\sum_{\mathrm{i}} r_{\mathrm{i}} \times W_{\mathrm{i}, y}
$$

ここで, $S_{y}$ は $y$ 年のスクラップ回収量, $W_{\mathrm{i}, y}$ は製品 $\mathrm{i} の y$ 年 に打ける使用済久製品中の素材排出推計量, $r_{\mathrm{i}}$ は製品 $\mathrm{i}$ の回 收率であり, 対象年 $y$ は 1991-1997 年, 用途 $\mathrm{i}$ は 6 用途を 示す符号とした. また, 自動車, 容器, その他製品以外の 3 用途の回収率は経年变化しないものとした. そのため, 対象 期間内の全製品平均の回収率は一定であることが望ましい。

Fig. 2 にその他製品用途の回収率として示す全製品平均の回 収率の経年变化を見ると, 1991 年から 1997 年においてほ ぼ一定であるため, その間を評価対象として設定した. 
(a) 1991

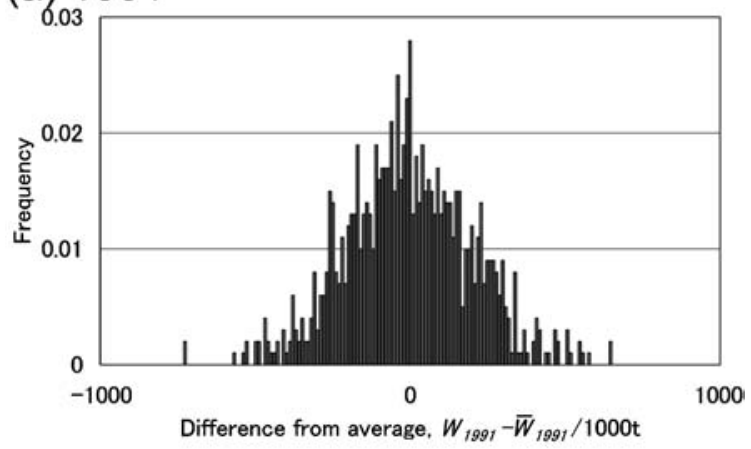

(b) 1997

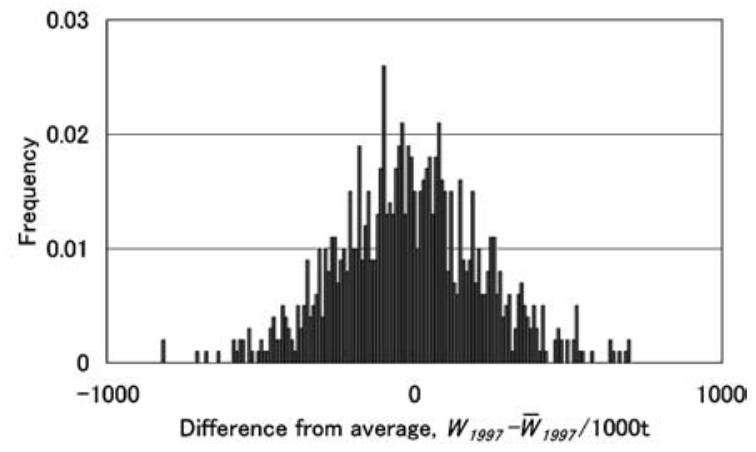

Fig. 3 Distribution of the amount of discarded steel expressed as a difference from the average in (a) 1991 and (b) 1998.

また，回収率は 0 以上 1 以下の数值となるため，それら を制約条件とし, 制約条件付き非線形最適化問題を, 数学的 最適化における解法の 1 つである降下法により導出した. なお，導出された残差最小和が制約条件内の極小值でないこ とを，初期值を 3125 点設定することにより確認した．導出 された回収率は，建築 1.000 ，土木 0.041 ，機械 0.509 であ った。このとき決定係数 $\mathrm{R}^{2}$ は 0.57 となり，観測ポイント数 において制約があったため，低い精度での分析となったこと がわかった。

\section{2 寿命分布の信頼幅}

本研究では, 小松 ${ }^{15)}$ が指摘する寿命分布関数の不確実性 を考慮し，それに伴う回収率の不確実性について，以下の方 法により検討した.

個々の製品が使用年数 $t$ 年の 1 年間に廃棄されるかどうか は，互いに独立な事象であるとすると，その 1 年間の廃棄 数はベルヌーイ試行によって得られると考えられる.ここ で，廃棄数は二項分布に従う確率変数と考えることができ， 次に示す手順によって寿命分布関数の信頼幅が推定した.

初期投入数 $N_{0}, t$ 年期首の残存数を $N_{t}$, 当該製品の残存確 率分布 $F(x)$, 廃棄密度関数 $f(x)$ とすると, $t$ 年の 1 年間の $N_{0}$ を母数とした廃棄確率は, 式 $(2)$ に示す $f(t)$ で表すこと ができる.ただし，関数 $F$ の指数 -1 は逆関数を表す.

$$
\begin{aligned}
f(t) & =F\left(x_{t}\right)-F\left(x_{t}+1\right) \\
& =\frac{N_{t}}{N_{0}}-F\left(F^{-1}\left(\frac{N_{t}}{N_{0}}\right)+1\right)
\end{aligned}
$$

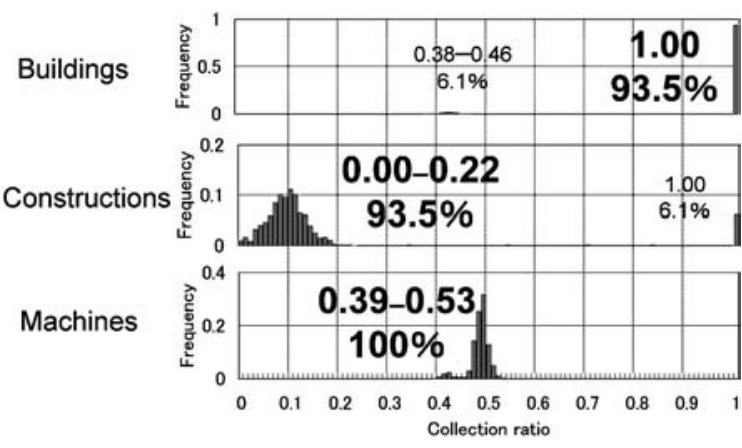

Fig. 4 Estimated collection ratios of buildings, constructions, and machines.

Table 1 Comparison between collection ratios estimated in this study and those in a previous study.

\begin{tabular}{lccccc}
\hline & \multicolumn{3}{c}{ Estimated collection ratio } & \\
\cline { 2 - 4 } & $\begin{array}{c}\text { With given } \\
\text { lifetime } \\
\text { distribution }\end{array}$ & $\begin{array}{c}\text { With uncertainty of } \\
\text { lifetime distribution }\end{array}$ & $\begin{array}{c}\text { Range of } \\
\text { Question- } \\
\text { naire } \\
\text { sollection } \\
\text { ratios }\end{array}$ & Average \\
survey & $\begin{array}{c}\text { Mean } \\
\text { value }\end{array}$ & \\
\hline Buildings & 1.00 & 1.00 & 0.96 & 1.00 & 0.50 \\
\hline Constructions & 0.04 & $0.00-0.22$ & 0.15 & 0.10 & 0.80 \\
\hline Machines & 0.51 & $0.39-0.53$ & 0.48 & 0.49 & 0 \\
\hline
\end{tabular}

次に, 計算機の中で一様乱数を発生させ，それを $B\left(N_{t}\right.$, $f(t))$ に従う二項分布乱数 $w_{t}$ に変換する. $N_{t+1}$ は， $N_{t}$ から $w_{t}$ を引くことで求められるため, $t+1$ 年に関しても同様の

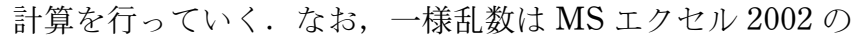
rand 関数により発生させた.この計算を 1000 回試行するこ とにより，使用済み製品中の素材排出量が Fig. 3 に示すよ うに数十万トンばらつくことがわかった．次に，それぞれの 試行結果から, 前節に記した手法により, 建築, 土木, 機械 の回収率を導出した結果を Fig. 4 に示す. 各用途の回収率 に颃いて，94\%程度の可能性で存在する幅を同定すること ができた。

\section{4. 考 察}

本研究において構築された手法により得られた結果をまと めると, Table 1のようになる. 本研究によって得られた建 築用途の回収率と土木用途の回収率を加重平均すると, 回収 率は 0.55-0.70の幅を持ち，平均值，中間值ともに 0.60 と なり，ヒアリング值と比較すると少し高い。また，建築用途 は土木用途よりも高い回収率を見込まれると考えられるた め, 妥当な結果と考えられる. 本研究によって得られた建築 用途の回収率は，1.00であったが，建築用途由来の鉄スク ラップのうちの一部は, 他素材と分離されることなく埋め立 てられていたことも考えられる。しかし，それらの量は多く はなく，ほぼ全量回収されていたと推計された。 また，得ら れた土木用途の回収率は，0.00-0.22であった。土木用途に はトンネルやダムなどの用途も含まれており，既往調查 ${ }^{21}$ 
によると，回収される可能性のないものが $39.8 \%$ あと言 われている，そのため，回収される可能性のある土木用途の うちの回収率に変換すると, 0.00-0.37 と考えられる. 今後 は，土木用途の詳細な分類や，フィールド調査による回収率 などのさらなる研究が望まれる．次に，研究によって得られ た機械用途の回収率は，ヒアリング值と比較すると低く推計 されたのがわかる。これは，機械用途に船舶が入っており， これらが国外で解体されていることが一因となっていると考 えられる．このように，本研究で構築した手法により，実測 が困難である製品回収率の同定の可能性を示すことができ た。

本研究においては, 統計データの比較的整備された鉄鋼材 に着目し解析手法を構築したが，他の素材においても，本手 法が適用可能であると考えられる，ただ，鉄鋼材はオーステ ナイト系ステンレスを除いて磁性を有するため，他素材との 分離が容易であるのに比べ, 他素材に提いては, 分離・分解 工程に打ける歩留まりに留意する必要があると考えられる.

\section{5. 結言}

本研究においては, 素材のマテリアルフローを基にして, 実測が困難である製品回収率が同定できる手法を構築した。 寿命分布関数の不確実性を考慮することにより，不確実性を 含む製品回收率を導出する手法が構築された，さらに，鉄鋼 材を例にとり 3 用途の回収率を導出することにより，得ら れた結果の妥当性も検討した.

今後は，区分の詳細化による解析精度の向上や，本手法の 他素材への適用による異なったデータを基にした製品回収率 の同定などのさらなる研究が望まれる.

本研究の推進にあたり，ご助言頂きました侏日鉄技術情報 センターの林＼cjkstart誠一参与に，御礼申し上げます。
文献

1) I. Daigo, Y. Matsuno, K. N. Ishihara and Y. Adachi: J. Iron Steel Inst. 91 (2005) 159-166.

2) EcoMaterial Forum, Recycling criteria working group: Recycling indicator guideline, 2004.9 , pp. $5-11$.

3) S. Hashimoto and Y. Terashima: Waste Management Research 11(2000) 271-279.

4) K. Yokota, Y. Matsuno, M. Yamashita and Y. Adachi: Int. J. LCA 8(2003) 129-136.

5) T. Tasaki, M. Koguchi, T. Kameya and K. Urano: Waste management research 12(2001) 29-58.

6) Y. Adachi, I. Daigo, H. Yamada and Y. Matsuno: Development Engineering 11(2005) 19-29.

7) I. Daigo, D. Fujimaki, Y. Matsuno and Y. Adachi: J. Iron Steel Inst. 91 (2005) 171-178.

8) I. Daigo, D. Fujimaki, Y. Matsuno and Y. Adachi: J. Iron Steel Inst. 91 (2005) 179-183.

9) T. E. Graedel, M. Vertram, K. Fuse, R. B. Gordon, R. Lifset, H. Rechberger and S. Spatari: Ecological Economics 42(2002) 926.

10) D. Vexler, M. Bertram, A. Kapur, S. Spatari and T. E. Graedel: Resour. conserv. Recycle. 41(2004) 23-46.

11) Road transport bureau Ministry of Land, Infrastructure and Transport, 1958-2004: Jidosha Hoyu Sharyosu 1-31, Automobile Inspection \& Registration Association, Tokyo.

12) K. Kakudate, Y. Adachi and T. Suzuki: Sci. Technol. Adv. Mater. 1(2000) 105

13) Committee on iron and steel statistics, The Japan Iron and Steel Federation (JISF): Handbook for Iron and Steel statistics (19712003), JISF, Tokyo (1971-2003).

14) Committee on iron and steel statistics, JISF: Futsuko Chiikibetsu Juchu Tokeihyo (1971-2003), JISF, Tokyo (1971-2003).

15) Y. Komatsu: Journal of Archit. Plann. Environ. Engng, AIJ 439 (1992) 91-99.

16) A. Toi and J. Sato: Energy and Resources 18(1999) 271-277.

17) The Japan ferrous raw materials association, Year book of ferrous raw materials 2004, Tokyo (2004) pp. 15, 19.

18) Japan automobile research institute: Kodo Gijutsu Shuyakugata Sangyoto Kenkyu Kaihatsu Chosa (Haisha Saishigenka, Haikibutu Taisaku Suishin Chosa) Hokokusho, Tokyo (2003) p. 13

19) Japan steel can recycling association: http://www.steelcan.jp/ recycle/report/rate2004.html, Status 2005/06/08.

20) K. Nakajima, W. Tamaki, D. Fujimaki and I. Daigo: J. Iron Steel Inst. 91 (2005) 150-153.

21) Japan technical information service: Dobokubumon niokeru Tetsu scrap Hasseisuikei (Japanese society of steel construction, Tokyo, 2003) p. 39. 